\title{
HYBRIDS OF WORLD POPULATIONS OF ALDROVANDA VESICULOSA
}

\author{
YoSHIAKI KATAGIRI • Niigata-City•Japan・katagirikashiten@kit.hi-ho.ne.jp
}

Keywords: Aquatic carnivorous plant, Droseraceae, hybrid traits, cultivation description.

\author{
Introduction
}

Aldrovanda vesiculosa L. (waterwheel plant, Droseraceae) is a rare and remarkable aquatic carnivorous plant with snapping traps living naturally on four continents of the Old World and introduced to North America (Breckpot 1997; Cross 2012; Fleischmann et al. 2018). Although Aldrovan$d a$ covers a huge territory within several climatic zones (temperate to tropical), it is highly scattered. A recent world-wide survey found only 50 sites, with the center of its distribution in Ukraine and Poland (Cross 2012; Adamec 2018). Aldrovanda is a monotypic genus without any subspecies, but its distant world populations usually differ in some physiological traits (turion formation, red coloration). However, in spite of these striking physical differences, the genetic differences between world populations (accessions) are surprisingly minimal (Adamec \& Tichý 1997; Maldonado San Martín et al. 2003; Hoshi et al. 2006; Elansary et al. 2010; Cross 2012; Adamec 2018). Although the flowers are opened for only a few hours (Adamec \& Tichý 1997; Cross 2012; Adamec 2018), under favorable conditions in all climatic zones, autogamous Aldrovanda can flower, self-pollinate, and set seed (Cross et al. 2016).

In 2007, after having a long-term experience in growing various Aldrovanda populations in my collection, I tried first to hybridize some strains of Aldrovanda plants under the following scheme: pollen acceptors $(+)$ were green-colored plants, while pollen donors $\left(\zeta^{\top}\right)$ were red-colored plants. In 2009, I could confirm some red-colored plants among the hybrids so that it has turned out that the hybridization has been successful. Afterwards, I continued to hybridize various world populations (also with both red parents) and have obtained many hybrids (or assumed hybrids).

\section{Methods}

I have been cultivating 15 strains of Aldrovanda from four continents for many years. They are grown outdoors in 10- to 15-liter plastic containers with rice straw and brown Sphagnum peat moss as substrates. Tropical strains are grown over winter in a heated greenhouse in 1- to 1.5-liter PET bottles with Sphagnum peat moss. However, most strains die before spring. Generally, the flowering season of Aldrovanda in my collection is from July to September and the best period for pollination is August. Thus, I conducted pollinations in August when each Aldrovanda population flowered on the same day. After removing pistils with anthers from a just opened Aldrovanda flower (†) using fine forceps, excised anthers from another strain $\left({ }^{\AA}\right)$ were put on the stigmas. These processes were conducted by hand and one may suppose that the emasculation is perfect and self-pollination might not occur.

In plants from (sub)tropical Australian populations, ripe seed is available one month after the pollination. However, in plants from temperate European and Japanese populations, more time was needed to obtain ripe seed. All seeds were harvested in September to October and stored in rain water in plastic vessels to avoid drying. Cultivation water was found to inhibit the subsequent seed 


\begin{tabular}{|c|c|c|c|c|c|c|c|}
\hline \multicolumn{2}{|c|}{ Parents abbrev. } & \multirow{2}{*}{$\begin{array}{l}\text { Year of } \\
\text { germin. }\end{array}$} & \multirow{2}{*}{$\begin{array}{l}\text { Growth } \\
\text { vigor }\end{array}$} & \multirow{2}{*}{$\begin{array}{l}\text { Flowering } \\
\text { frequency }\end{array}$} & \multirow[t]{2}{*}{ Shoot color } & \multirow{2}{*}{$\begin{array}{l}\text { Cold } \\
\text { tolerance }\end{array}$} & \multirow{2}{*}{$\begin{array}{c}\text { Turion } \\
\text { formation }\end{array}$} \\
\hline q & $\hat{\sigma}$ & & & & & & \\
\hline $\mathrm{P}$ & $\mathbf{W}$ & 2009 & moderate & good & $\mathrm{red} /$ green & $\begin{array}{l}\text { low to } \\
\text { moderate }\end{array}$ & $\mathrm{Y}$ \\
\hline $\mathrm{K}$ & D & 2009 & good & moderate & slightly red & low & $\mathrm{N}$ \\
\hline $\mathrm{P}$ & $\mathbf{S}$ & 2009 & moderate & $\begin{array}{l}\text { low to } \\
\text { moderate }\end{array}$ & slightly red & moderate & $\mathrm{Y}$ \\
\hline $\mathbf{R}$ & $\mathbf{W}$ & 2010 & moderate & moderate & red & moderate & $\mathrm{Y}$ or $\mathrm{N}$ \\
\hline $\mathrm{H}$ & $\mathbf{L}$ & 2010 & moderate & $\begin{array}{l}\text { low to } \\
\text { moderate }\end{array}$ & slightly red & $\begin{array}{l}\text { low to } \\
\text { moderate }\end{array}$ & $\mathrm{Y}$ \\
\hline I & B & 2010 & moderate & $\begin{array}{l}\text { low to } \\
\text { moderate }\end{array}$ & slightly red & $\begin{array}{l}\text { low to } \\
\text { moderate }\end{array}$ & $\mathrm{Y}$ \\
\hline $\mathbf{L}$ & D & 2010 & low to good & moderate & red & moderate & $\mathrm{Y}$ \\
\hline $\mathbf{T}$ & $\mathbf{A}$ & 2010 & moderate & good & slightly red & $\begin{array}{l}\text { moderate } \\
\text { to high }\end{array}$ & $\mathrm{Y} ?$ \\
\hline $\mathbf{S}$ & $\mathrm{K}$ & 2010 & moderate & $\begin{array}{l}\text { low to } \\
\text { moderate }\end{array}$ & slightly red & $\begin{array}{l}\text { low to } \\
\text { moderate }\end{array}$ & $\mathrm{Y}$ \\
\hline B & $\mathbf{L}$ & 2012 & good & good & red & $\begin{array}{l}\text { low to } \\
\text { moderate }\end{array}$ & Y or $\mathrm{N}$ \\
\hline $\mathrm{V}$ & $\mathbf{W}$ & 2014 & moderate & moderate & slightly red & moderate & $\mathrm{Y}$ \\
\hline $\mathrm{V}$ & $\mathbf{E}$ & 2014 & moderate & $\begin{array}{l}\text { low to } \\
\text { moderate }\end{array}$ & slightly red & $\begin{array}{l}\text { low to } \\
\text { moderate }\end{array}$ & $\mathrm{N}$ \\
\hline $\mathbf{E}$ & $\mathbf{S}$ & 2016 & moderate & moderate & red & low & $\mathrm{N} ?$ \\
\hline $\mathrm{P}$ & D & 2017 & moderate & good & slightly red & moderate & $\mathrm{Y}$ \\
\hline
\end{tabular}

germination and, thus, only rainwater was used. The vessels were stored over winter in light on a window ledge in a non-heated room. I usually keep the overwintering Aldrovanda seed in light by the window as this species prefers light-induced germination (Cross 2012; Cross et al. 2016). Other stock seed is kept in darkness.

At the beginning of February, the water in the vessels was removed and the seeds were air dried. After two weeks, water was added into the vessels again. I usually use rain water, but a boiled-water extract with peat moss being properly diluted by rain water is preferable. In March, the vessels with seeds were transferred to a non-heated greenhouse so that the seeds were exposed to a sufficient light intensity. The seeds germinated regularly in May or June. However, in some cases, they did not germinate until the following year.

F1 hybrids, primary hybridization

For hybridizations, I used 12 parental Aldrovanda populations, which are referred to by the following abbreviations (see Elansary et al. 2010): A: Armidale county, N.S.W., E Australia; B: 
Okavango delta, Botswana; D: S of Darwin, N.T., N Australia; E: Esperance Bay, W.A., SW Australia; H: Hanyu city, near Tokyo, Japan; I: Lake Ogura, near Kyoto (from Mr. Ishitaka); K: Lake Ogura, near Kyoto (from Mr. Naitou); L: Katherine, N.T., N Australia; P: E Poland; R: Lake Baláta-tó, Somody county, SW Hungary; S: Browlee near Sydney, N.S.W., SE Australia (from Mr. Kimura); T: probably Browlee near Sydney, N.S.W., SE Australia (from Mr. Takahashi); V: Danube delta, Romania; W: Kimberley, N.T., NW Australia.

So far, I have produced many F1 hybrids. In this review, I state only those which survived or have strongly remarkable traits (Table 1, see Figs. 1-3). When hybridization between red-colored strains was conducted, it was impossible to reliably identify the hybrid seedlings or young plants. Growing Aldrovanda populations for years, I estimated that hybrids possessed certain kind of a heterosis effect. I usually consider a heterosis effect if the hybrid plants withstand a one-year cultivation in a $500 \mathrm{~mL}$ PET bottle with Sphagnum peat moss as nutrient-poor conditions. Generally, under these conditions, wild parental strains cannot grow well or die soon.

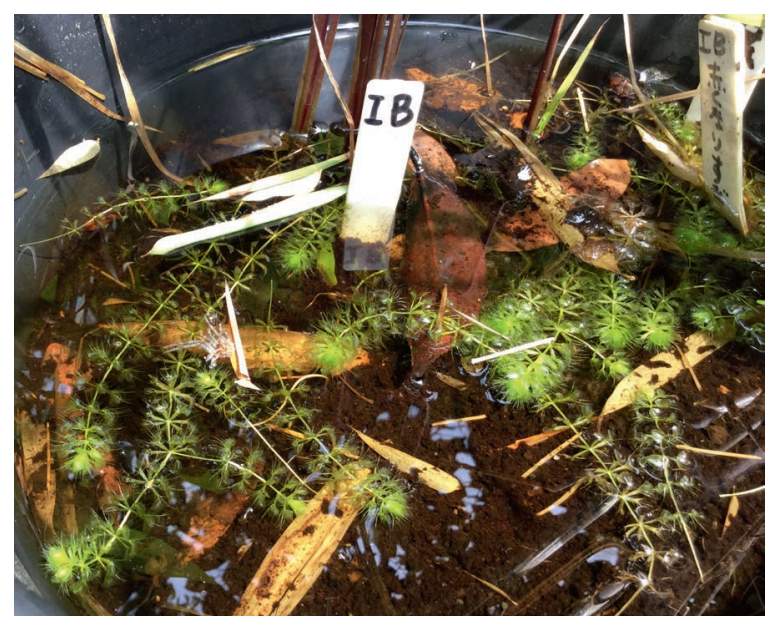

Figure 1: Hybrid IB Aldrovanda plants can be only slightly red, July 17, 2018.

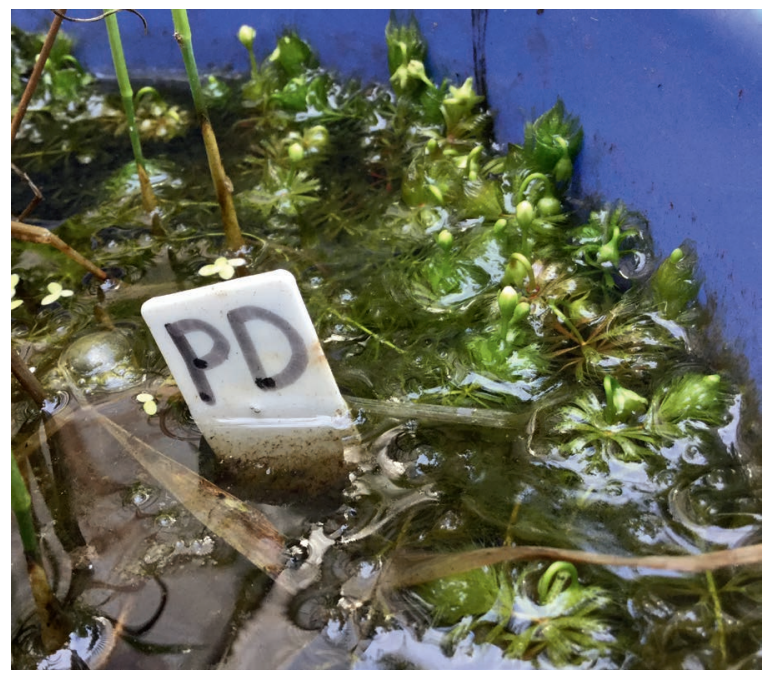

Figure 2: Hybrid PD Aldrovanda plants form abundant flowers, July 24, 2018.

F1 hybrids, multiple hybridization

Multiple hybridizations of F1 hybrids among various Aldrovanda populations resulted in various combinations of traits of F1 plants. However, in these hybridizations, self-pollination is included and it is thus hard to distinguish them clearly from each other. These hybrids were grown in small containers and kept under stress conditions at low above $0^{\circ} \mathrm{C}$ temperatures during winter season in order to select healthy plants. The following hybrids have survived: $\mathrm{PW} \times \mathrm{KD}$ (germinated 2011); $\mathrm{IB} \times \mathrm{BL}(2013) ; \mathrm{KD} \times \mathrm{BL}(2013) ; \mathrm{V} \times(\mathrm{S} \times$ probably D, 2014); $\mathrm{BL} \times(\mathrm{KD} \times \mathrm{PW}, 2015) ; \mathrm{BL} \times(\mathrm{IB}$ or PW2 $\times$ V, 2015); BL × (KD × PW × ??, 2015); IB × V (2016); V × IB (2016); PW × IB (2016). 
I conducted also several F2 hybridizations. The seeds and young plants from the same parents produced a great variability of all traits. Only two strains have survived finally. The hybrid PW2, which originated by selfpollination of the PW parents, had a moderate growth, its flowering was scored as moderate to good, its color could be green to (slightly) red, its cold tolerance was low to moderate, and it can sometimes form turions. The hybrid KD2 produced a good growth, its color could be green to slightly red, it had a low cold tolerance, and did not form turions. Its flowering traits are unknown.

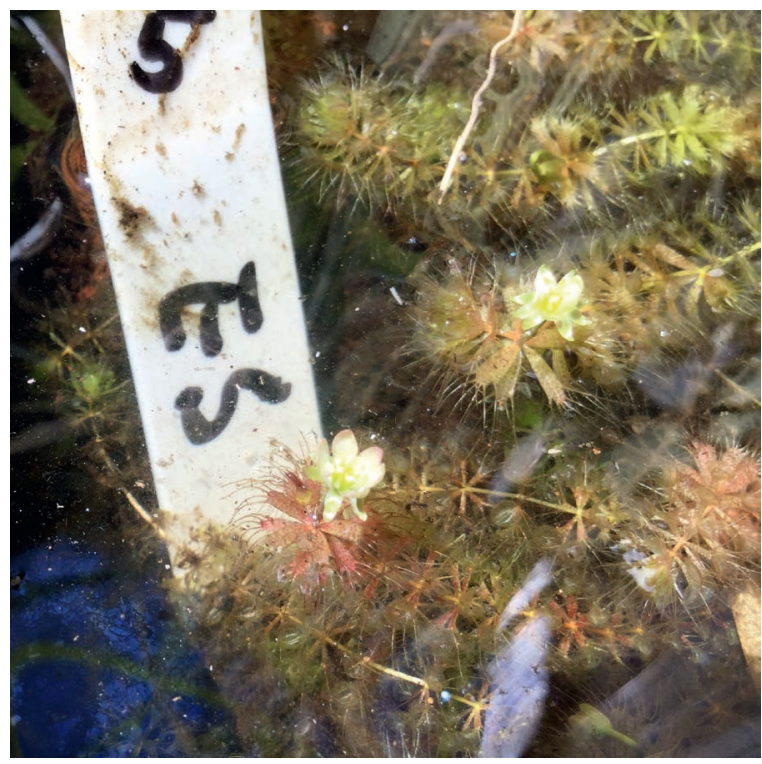

Figure 3: Hybrid ES Aldrovanda plants are distinctly red and commonly flower, August 23, 2018.

\section{Conclusions}

Out of 12 worldwide parental Aldrovanda populations, I have succeeded in creating 14 confirmed hybrids so far. The hybrids between tropical and temperate populations also exhibit vigorous growth. All hybrids are fully fertile and normally set viable seeds. They have more or less intermediate traits as compared to their parents. It was not possible to decide reliably in some hybrids (RW and TA) whether or not they form turions. However, it seems that in the most cases with a few exceptions (KD, VE), if one of the parents (either from temperate or tropical populations or as pollen acceptor or donor) forms turions, also the hybrid forms turions. The same principle, without any exceptions, applies for red coloration by anthocyanins. It can thus be concluded that both dormant turion formation and anthocyanin production have a genetically dominant character (Adamec 2018).

Acknowledgements: I greatly appreciate all who provided parental populations. They were $\mathrm{Mr}$. Takayoshi Kimura, Drs. Michiaki Mabuchi and Lubomír Adamec. Sincere thanks are due to Drs. Lubomír Adamec and Hiro Shimai, who gave me many pieces of helpful advice, and to Mr. Yukio Kosaka and Mr. Kazuyuki Takizawa, who kindly translated the literature to Japanese or English.

\section{References}

Adamec, L. 2018. Biological flora of Central Europe: Aldrovanda vesiculosa L. Perspect. Plant Ecol. Evol. Syst. 35: 8-21.

Adamec, L., and Tichý, M. 1997. Flowering of Aldrovanda vesiculosa in outdoor culture in the Czech Republic and isozyme variability of its European populations. Carniv. Pl. Newslett. 26(3): 99-103. 
Breckpot, C. 1997. Aldrovanda vesiculosa: description, distribution, ecology, and cultivation. Carniv. P1. Newslett. 26(3): 73-82.

Cross, A. 2012. Aldrovanda. The Waterwheel Plant. Redfern Natural History Productions, Poole, Dorset, England.

Cross, A.T., Adamec, L., Turner, S.R., Dixon, K.W., and Merritt, D.J. 2016. Seed reproductive biology of the rare aquatic carnivorous plant Aldrovanda vesiculosa (Droseraceae). Bot. J. Linn. Soc. 180: 515-529.

Elansary, H.O.M., Adamec, L., and Štorchová, H. 2010. Uniformity of organellar DNA in Aldrovanda vesiculosa, an endangered aquatic carnivorous species, distributed across four continents. Aquat. Bot. 92: 214-220.

Fleischmann, A., Cross, A.T., Gibson, R., Gonella, P.M., and Dixon, K.W. 2018. Systematics and evolution of Droseraceae. In: Ellison, A.M., and Adamec, L. (eds.), Carnivorous Plants: Physiology, Ecology, and Evolution. Oxford University Press, Oxford, U.K., pp. 45-57.

Hoshi, Y., Shirakawa, J., and Hasebe, M. 2006. Nucleotide sequence variation was unexpectedly low in an endangered species, Aldrovanda vesiculosa L. (Droseraceae). Chromos. Bot. 1: 27-32. Maldonado San Martín, A.P., Adamec, L., Suda, J., Mes, T.H.M., and Štorchová, H. 2003. Genetic variation within the endangered species Aldrovanda vesiculosa (Droseraceae) as revealed by RAPD analysis. Aquat. Bot. 75: 159-172.

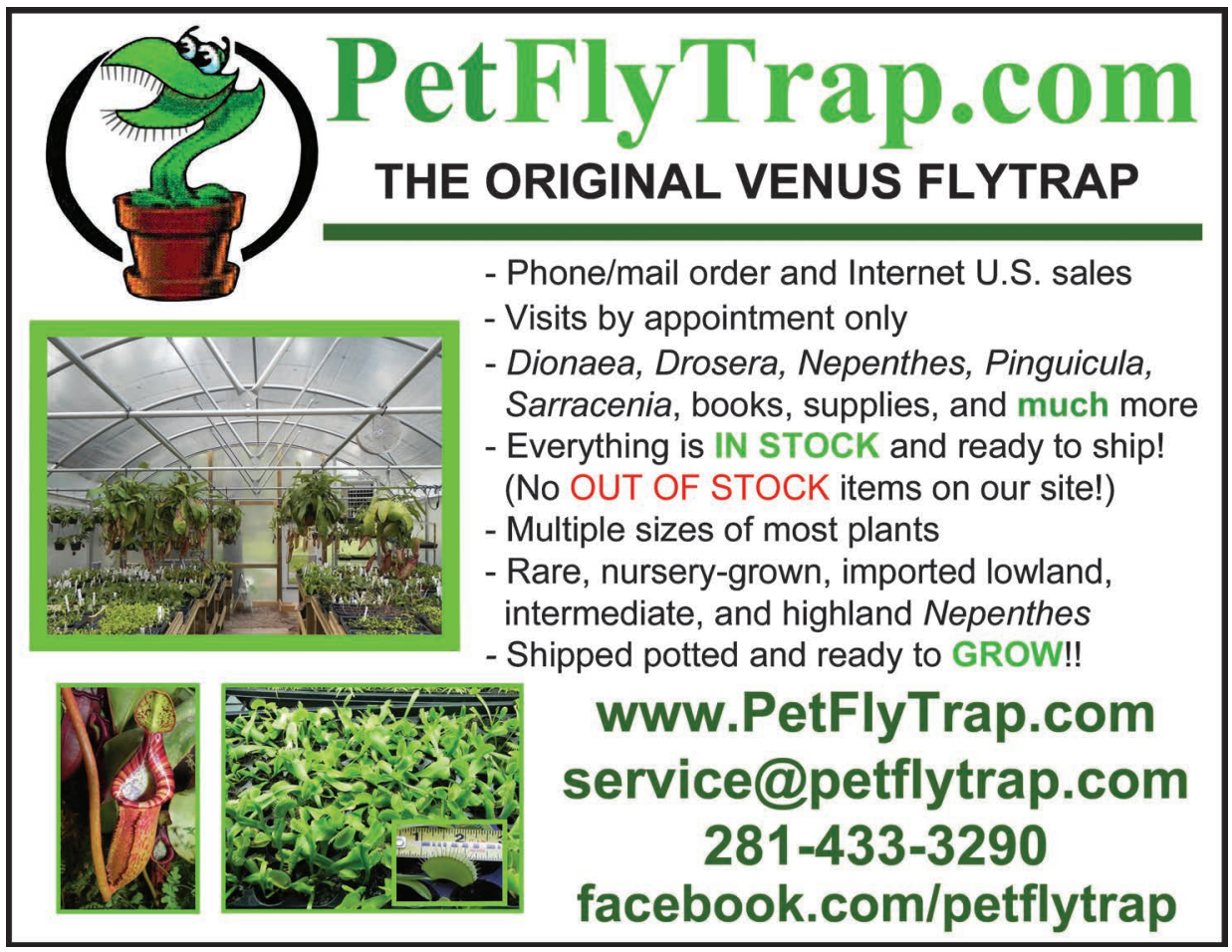

